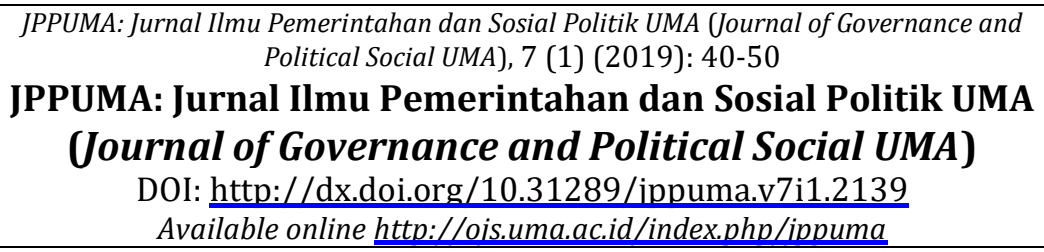

JPPUMA: Jurnal Ilmu Pemerintahan dan Sosial Politik UMA

(Journal of Governance and Political Social UMA)

DOI: http://dx.doi.org/10.31289/ippuma.v7i1.2139

Available online http://ojs.uma.ac.id/index.php/ippuma

\title{
Pelaksanaan Program Gerakan Pensejahteraan Ekonomi Masyarakat Pesisir dan Dampaknya di Kelurahan Pasie Nan Tigo, Kota Padang
}

\section{Implementation of Coastal Community Economic Welfare Program and Its Impact in Pasie Nan Tigo Subdistrict, Padang City}

\author{
Thahira Kemala Dewi'1)*, Asdi Agustar2) \& Mahdi ${ }^{3)}$ \\ 1) Jurusan Pembangunan Wilayah dan Pedesaan, Fakultas Pascasarjana, Universitas Andalas, Indonesia \\ 2) Jurusan Sosial Ekonomi Peternakan, Fakultas Peternakan, Universitas Andalas, Universitas Andalas, \\ Indonesia \\ 3) Jurusan Sosial Ekonomi Pertanian, Fakultas Pertanian, Universitas Andalas, Indonesia. \\ Diterima: Desember 2018; Disetujui: Februari 2019; Dipublish: Juni 2019
}

\begin{abstract}
Abstrak
Penelitian ini bertujuan untuk mengetahui bagaimana Program Gerakan Pensejahteraan Ekonomi Masyarakat Pesisir (GPEMP) dilaksanakan dan dampaknya terhadap orientasi sumber pendapatan keluarga nelayan di Kelurahan Pasie Nan Tigo Kecamatan Koto Tangah Kota Padang. Metode yang digunakan pada penelitian ini adalah metode studi kasus dengan informan-informan kunci sebagai sumber data utama. Dilakukan wawancara pada informan kunci dan pengamatan langsung di lapangan terkait dengan masalah - masalah yang diangkat dalam penelitian ini. Analisis data melalui pendekatan kualitatif.Hasil penelitian didapatkan bahwa program GPEMPsudah dilaksanakan sesuai dengan petunjuk pelaksanaan, kecuali dalam tahap penyerahan bantuan GPEMP yaitu bantuan pengembangan budidaya ikan dengan bantuan berupa paket jaring tancap dan peralatan budidaya nila dimana ada terdapat perbedaan spesifikasi barang yang diserahkan dengan yang seharusnya. Program GPEMP memberikan dampak terhadap orientasi sumber pendapatan keluarga nelayan di kelurahan Pasie Nan Tigo, yaitu: 1) jenis sumber pendapatan keluarga nelayan tidak hanya dari penangkapan ikan tetapi juga dari mata pencaharian alternatif sebagai sumber pendapatan baru yaitu budidaya ikan, diversifikasi pengolahan ikan, dan beternak sapi; dan 2) serapan jam kerja tenaga kerja nelayan bertambah serta adanya keterlibatan istri dan anak nelayan dalam melakukan usaha.
\end{abstract}

Kata Kunci: Program Gerakan Pensejahteraan Ekonomi Masyarakat Pesisir, jenis sumber pendapatan, Keluarga Nelayan, Serapan Jam Kerja.

\section{Abstract}

This study aims to discover how The Coastal Community Economic Welfare Program (GPEMP) programwas implemented and its impact on the orientation of fishermen's family income-sources in Pasie Nan Tigo Subdistrict, Koto Tangah District, Padang City. The method used in this study is a case study method with key informants as the main data source. Interviews were conducted with key informants and direct observations in the field related to the problems raised in this study.Data analysis through a qualitative approach.The results showed that the GPEMP program had been implemented in accordance with the implementation instructions, except in the GPEMP assistance delivery phase, namely the assistance of developing fish culture with the help of a fixed net package and tilapia cultivation equipment where there were differences in the specifications of the goods delivered with the supposed ones. The GPEMP program has impacts on the orientation of fishermen's family income sources in Pasie Nan Tigo Subistrict, namely: 1) fishermen's family income sources developed to become not only from fishing, but also from other new alternative livelihoods, such as fish cultivation, fish processing diversification, and cattle farming, and 2) fishermen's effectiveness working hours increases as well as involvement of fishermen's wives and children's involvement in the business.

Keywords: fishermen family, The Coastal Community Economic Welfare Program, Types of Income Sources, Working Hour Effectiveness.

How to Cite: Dewi, T.K. Agustar, A. Mahdi (2019). Pelaksanaan Program Gerakan Pensejahteraan Ekonomi Masyarakat Pesisir dan Dampaknya di Kelurahan Pasie Nan Tigo, Kota Padang. JPPUMA: Jurnal Ilmu Pemerintahan dan Sosial Politik UMA, (Journal of Governance and Political Social UMA), 7 (1): 40-50

*Corresponding author: ISSN 2549-1660 (Print)

E-mail: thahira.kemala.dewi@gmail.com ISSN 2550-1305 (Online) 


\section{PENDAHULUAN}

Peranan wilayah pesisir dan lautan menjadi bagian penting dari kegiatan pembangunan perekonomian Indonesia. Secara ekonomis wilayah ini menjanjikan potensi komersial yang sangat besar karena memiliki kekayaan dan keanekaragaman sumber daya alam yang dapat pulih (renewable resources, perikanan, terumbu karang, mangrove, padang lamun, rumput laut, dan sebagainya), yang tidak dapat pulih (unrenewable resources, minyak dan gas, bahan tambang) dan jasa lingkungan (environmental services, pariwisata, perhubungan, energi kelautan, mitigasi bencana dan sebagai penyimpanan atau penyerap karbon sehingga mengurangi perubahan iklim) (Dahuri, et al., 1996).

Sumatera Barat memiliki potensi kelautan dan perikanan yang relatif besar, seperti: memiliki panjang garis pantai 1,973.246 km sudah termasuk Kabupaten Kepulauan Mentawai, potensi sumber daya perikanan laut yang cukup menjanjikan, antara lain ikan pelagis besar seperti tuna, cakalang, tongkol dan tenggiri, ikan pelagis kecil, ikan demersal, udang, ikan karang, lobster dan cumi-cumi sebesar 565,100 ton per tahun, pulau-pulau kecil 185 buah, potensi mangrove 42,105.91 Ha, dan terumbu karang 39,982.16 $\mathrm{Ha}$, potensi padang lamun 2,350.81 Ha dan terdapat juga 32 lokasi pendaratan penyu serta telah diakomodir enam kawasan menjadi Kawasan Konservasi Laut Daerah (KKLD). Selain potensi perikanan yang terdapat di laut, Sumatera Barat juga mempunyai potensi perikanan perairan umum sebesar $66.896,63$ Ha yang terdiri dari danau, sungai, telaga, rawa dan lain-lain dan tersebar pada 19 Kabupaten/Kota. Luas perairan umum tersebut diatas yang mempunyai potensi untuk perikanan budidaya adalah sebesar 1,306 Ha (Tim Kerja Kajian Dampak GPEMP Sumatera Barat, 2015).

Potensi sumber daya kelautan dan perikanan yang relatif besar tersebut ternyata belum mampu memberikan kesejahteraan bagi masyarakat terutama masyarakat pesisir khususnya nelayan. Berdasarkan data kemiskinan dari Pendataan Program Perlindungan Sosial (PPLS) tahun 2008 yang dilakukan oleh Badan Pusat Statistik (BPS), jumlah rumah tangga miskin nelayan di pesisir Sumatera Barat sebesar 5.680 KK atau sekitar
94,79\% dari seluruh rumah tangga miskin sektor perikanan di Sumatera Barat yang berjumlah $6.972 \mathrm{KK}$.

Tabel 1. Sebaran Jumlah Rumah Tangga Nelayan Miskin di Sumatera Barat

\begin{tabular}{lll}
\hline No & Kabupaten / Kota & $\begin{array}{l}\text { Rumah } \\
\text { Miskin (KK) }\end{array}$ \\
\hline 1 & Pasaman Barat & 1,827 \\
2 & Agam & 125 \\
3 & Padang Pariaman & 338 \\
4 & Pariaman & 129 \\
5 & Padang & 1,190 \\
6 & Pesisir Selatan & 1,861 \\
7 & Kepulauan Mentawai & 210 \\
\hline & Jumlah & $\mathbf{5 , 6 8 0}$ \\
\hline
\end{tabular}

Sumber : Tim Kerja Kajian Dampak GPEMP Sumatera Barat. 2015

Potensi sumber daya kelautan dan perikanan yang relatif besar tersebut ternyata belum mampu memberikan kesejahteraan bagi masyarakat terutama masyarakat pesisir khususnya nelayan. Berdasarkan data kemiskinan dari Pendataan Program Perlindungan Sosial (PPLS) tahun 2008 yang dilakukan oleh Badan Pusat Statistik (BPS), jumlah rumah tangga miskin nelayan di pesisir Sumatera Barat sebesar $5.680 \mathrm{KK}$ atau sekitar 94.79\% dari seluruh rumah tangga miskin sektor perikanan di Sumatera Barat yang berjumlah 6,972 KK.

Masyarakat pesisir yang identik dengan nelayan merupakan bagian dari masyarakat terpinggirkan yang masih terus bergulat dengan berbagai persoalan kehidupan, baik ekonomi, sosial, maupun budaya. Kondisi kehidupan yang memprihatinkan, terutama secara ekonomi, dengan penghasilan yang selalu tergantung pada kondisi alam, maka akan sulit untuk merubah kehidupannya menjadi lebih baik. Pembangunan dikawasan pesisir pada umumnya dikaitkan dengan pengentasan kemiskinan nelayan yang kehidupannya selalu bergantung pada penangkapan ikan di laut.

Menurut Kusnadi (2002), faktor penyebab kemiskinan nelayan terbagi dalam dua kelompok. Pertama, kemiskinan nelayan yang bersifat internal mencakup: 1) keterbatasan kualitas sumber daya manusia nelayan; 2) keterbatasan kemampuan modal usaha dan teknologi penangkapan; 3) hubungan kerja dalam organisasi penangkapan yang seringkali kurang menguntungkan buruh; 4) kesulitan melakukan diversifikasi usaha penangkapan; 
5) ketergantungan yang tinggi terhadap okupasi melaut; dan 6) gaya hidup yang dipandang boros, sehingga kurang berorientasi ke masa depan.

Kedua, kemiskinan yang bersifat eksternal mencakup: 1) kebijakan pembangunan perikanan yang lebih berorientasi pada produktivitas untuk menunjang pertumbuhan ekonomi nasional dan parsial; 2) sistem pemasaran hasil perikanan yang lebih menguntungkan pedagang perantara; 3) kerus akan ekosistem pesisir dan laut karena pencemaran dari wilayah darat, praktek penangkapan ikan dengan bahan kimia, perusakan terumbu karang, dan konversi hutan bakau di kawasan pesisir; 4) Penggunaan peralatan tangkap ikan yang tidak ramah lingkungan; 5) Penegakan hukum yang lemah terhadap perusak lingkungan; 6) terbatasnya teknologi pengolahan pasca panen; 7) terbatasnya peluang kerja di sektor non-perikanan yang tersedia di desa nelayan; 8) kondisi alam dan fluktuasi musim yang tidak memungkinkan nelayan melaut sepanjang tahun; dan 9) isolasi geografis desa nelayan yang menganggu mobilitasbarang, jasa, modal dan manusia.

Rumah tangga nelayan memiliki ciri khusus seperti penggunaan wilayah pesisir dan laut (common property) sebagai faktor produksi, jam kerja harus mengikuti oseanografis. Demikian juga pekerjaan menangkap ikan adalah pekerjaan yang penuh resiko, sehingga pekerjaan ini umumnya dikerjakan oleh lelaki. Hal ini mengandung arti bahwa keluarga yang lain (istri ataupun anak perempuan) tidak dapat membantu secara penuh, sehingga masyarakat yang tinggal di wilayah pesisir pada umumnya sering diidentikkan dengan masyarakat miskin (Novita, 2016).

Penghasilan seorang nelayan tradisonal tidak bisa diandalkan untuk memenuhi kebutuhan sehari-hari yang tiap hari semakin melambung. Jika nelayan tradisional hanya mengandalkan pendapatanya dari hasil melaut maka kehidupan mereka tidak akan berubah, oleh karena itu untuk menunjang penghasilanya perlu kiranya pekerjaan alternatif untuk menambah pendapatan serta untuk pemenuhan kebutuhan hidup seharihari mereka. (Hamdani, 2013).

Keadaan tersebut penting untuk menjadi perhatian yang serius oleh pemerintah, swasta dan masyarakat itu sendiri untuk melakukan upaya percepatan mengatasinya. Upaya yang diyakini secara cepat dapat mengatasi permasalahan masyarakat pesisir / nelayan diatas adalah mengembangkan jumlah jenis usaha setiap rumah tangga nelayan dan masyarakat pesisir lainnya untuk mencapai efesiensi dalam usaha perikanan terpadu yang saling menguntungkan dimana setiap masyarakat pesisir minimal dapat berusaha dengan dua atau lebih kegiatan perikanan yang dipadukan dengan kegiatan sektor lainnya seperti pertanian, peternakan, industri dan sebagainya. Salah satu program yang dilaksanakan oleh Pemerintah Provinsi Sumatera Barat dalam rangka pengentasan kemiskinan di wilayah pesisir adalah Program Gerakan Pensejahteraan Ekonomi Masyarakat Pesisir (GPEMP). Tujuan program Gerakan Terpadu Pensejahteraan Masyarakat Pesisir adalah untuk pengentasan kemiskinan bagi rumah tangga masyarakat di wilayah pesisir dengan peningkatan jam kerja efektif melalui integrasi usaha terpadu dengan keterampilan lain seperti berkebun dan bertani, dan sebagainya.

Tabel 2. Sebaran Jumlah Rumah Tangga Nelayan Miskin di Kota Padang

\begin{tabular}{|c|c|c|c|}
\hline No & Kecamatan & Kelurahan & $\begin{array}{l}\text { RTM } \\
\text { (KK) }\end{array}$ \\
\hline 1 & $\begin{array}{l}\text { Bungus Teluk } \\
\text { Kabung }\end{array}$ & $\begin{array}{l}\text { Bungus Barat } \\
\text { Bungus Selatan } \\
\text { Tl. Kabung Selatan } \\
\text { Tl. Kabung Utara }\end{array}$ & $\begin{array}{l}40 \\
80 \\
3 \\
106\end{array}$ \\
\hline 2 & Lubuk Begalung & $\begin{array}{l}\text { Tl. Kabung Tengah } \\
\text { Gates Nan XX }\end{array}$ & $\begin{array}{l}49 \\
287\end{array}$ \\
\hline \multirow[t]{4}{*}{3} & Padang & Teluk Bayur & 6 \\
\hline & Selatan & Air Manis & 26 \\
\hline & & Batang Arau & 72 \\
\hline & & Bukit Gado -Gado & 1 \\
\hline \multirow[t]{4}{*}{4} & Padang Barat & Berok Nipah & 38 \\
\hline & & Purus & 61 \\
\hline & & Olo & 6 \\
\hline & & Rimbo Kaluang & 33 \\
\hline \multirow[t]{2}{*}{5} & Padang Utara & Lolong Belanti & 14 \\
\hline & & $\begin{array}{l}\text { Ulak Karang } \\
\text { Selatan } \\
\text { Air Tawar Barat }\end{array}$ & $\begin{array}{l}53 \\
48\end{array}$ \\
\hline \multirow[t]{4}{*}{6} & Koto Tangah & $\begin{array}{l}\text { Parupuak Tabing } \\
\text { Padang Sarai }\end{array}$ & $\begin{array}{l}54 \\
5\end{array}$ \\
\hline & & Pasia Nan Tigo & 180 \\
\hline & & $\begin{array}{l}\text { Bungo Pasang } \\
\text { Lubuk Buayo }\end{array}$ & $\begin{array}{l}11 \\
17 \\
\end{array}$ \\
\hline & Jumlah & 22 & $\begin{array}{l}1,19 \\
0\end{array}$ \\
\hline
\end{tabular}


Sumber: Tim Kerja Kajian Dampak GPEMP Sumatera Barat. 2015

Program ini menggunakan data kemiskinan PPLS tahun 2008 yang dilakukan oleh BPS. Data kemiskinan tersebut dijadikan sebagai basis gerakan program yang dilaksanakan pada tahun 2012 s.d. 2015. Sasaran pelaksanaan program GPEMP adalah terbinanya usaha ekonomi rumah tangga miskin sektor perikanan di wilayah pesisir sebanyak 5,680 KK yang tersebar pada tujuh kabupaten/kota wilayah pesisir yang terdiri dari 42 kecamatan dan 89 nagari/desa/kelurahan. Dan untuk Kota Padang, terdapat 1,190 KK miskin yang tersebar di enam kecamatan (Kecamatan Padang Utara, Kecamatan Padang Barat, Kecamatan Padang Selatan, Kecamatan Koto Tangah, Kecamatan Bungus Teluk Kabung dan Kecamatan Lubuk Begalung) dan 22 kelurahan.

Di sepanjang kawasan pesisir Kota Padang, Kelurahan Pasie Nan tigo Kecamatan Koto Tangah merupakan salah satu sentra perikanan sekaligus pemukiman masyarakat pesisir. Namun, dari data diatas dapat dilihat bahwa kelurahan ini merupakan salah satu kelurahan dengan jumlah Kepala Keluarga (KK) miskin terbanyak yaitu urutan kedua jumlah KK miskin terbanyak dari data keseluruhan jumlah KK miskin di Kota Padang.

Secara umum tujuan yang ingin dicapai dalam penelitian ini adalah untuk melihat bagaimana kinerja Program Gerakan Pensejahteraan Ekonomi Masyarakat Pesisir (GPEMP) ini mampu untuk mengatasi masalah kemiskinan khususnya bagi nelayan di wilayah pesisir. Secara rinci tujuan penelitian ini adalah : 1) Untuk mengetahui bagaimana Program Gerakan Pensejahteraan Masyarakat Ekonomi Pesisir (GPEMP) dilaksanakan di Kelurahan Pasie Nan Tigo dan 2) Untuk menganalisis dampak Program GPEMP terhadap orientasi sumber pendapatan keluarga nelayan di Kelurahan Pasie Nan Tigo Kecamatan Koto Tangah Kota Padang.

\section{METODE PENELITIAN}

Penelitian ini akan dilakukan di Kecamatan Koto Tangah Kota Padang. Metode yang digunakan dalam penelitian ini adalah metode studi kasus. Studi kasus adalah merupakan salah satu strategi dalam sebuah penelitian kualitatif. Menurut John W.
Creswell, studi kasus merupakan strategi penelitian dimana di dalamnya peneliti menyelidiki secara cermat suatu program, peristiwa, aktivitas, proses, atau sekelompok individu. Untuk lebih jelasnya lokasi penelitian dapat dilihat pada peta yang ditunjukkan pada Gambar 1 dan 2.

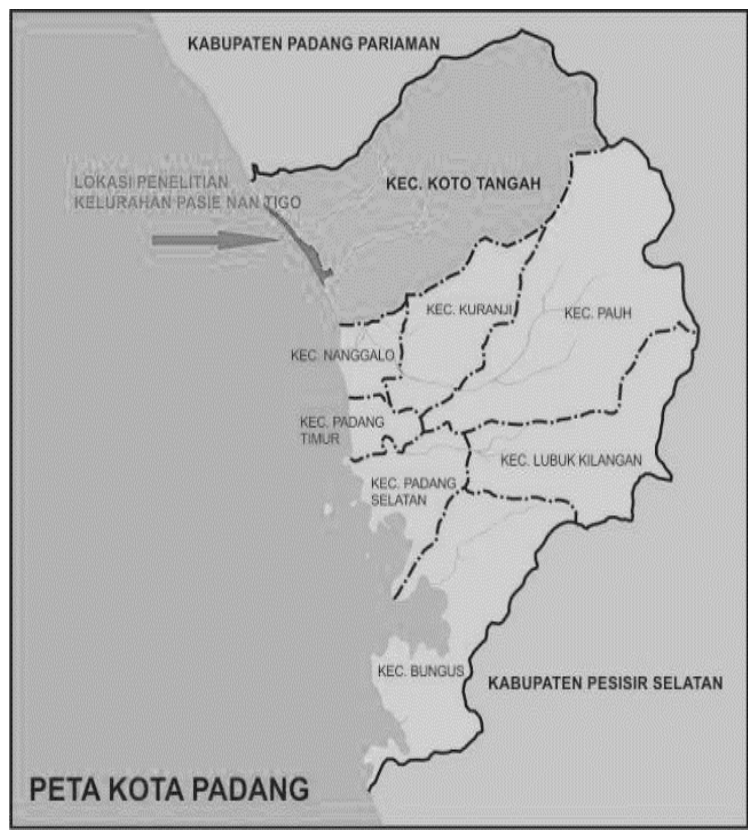

Gambar 1. Peta Lokasi Penelitian

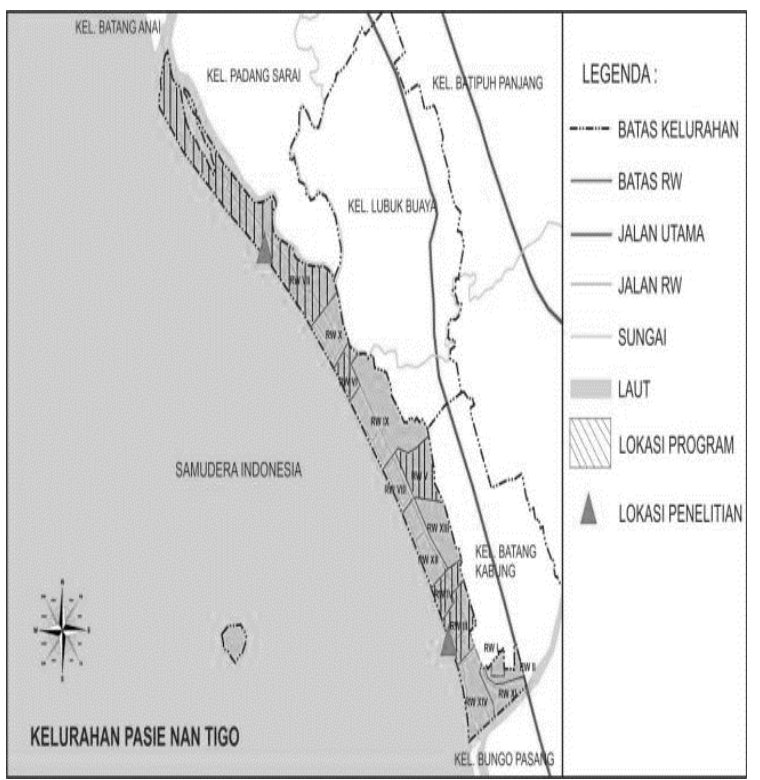

Gambar 2. Peta Lokasi Penelitian

Penelitian di Kelurahan Pasie Nan Tigo dilakukan dengan wawancara langsung pada informasi kunci serta pengamatan langsung di 
lapangan terkait dengan masalah-masalah yang diangkat dalam penelitian ini.

Jenis data yang dikumpulkan dalam penelitian ini terdiri dari data primer dan data sekunder. Data primer diperoleh dengan informan kunci yang terdiri dari unsur pemerintah (lurah), pembimbing teknis di kelurahan, anggota masyarakat terkemuka dan penerima manfaat.

Sedangkan jenis data sekunder di peroleh dari lembaga dan instansi terkait dengan penelitian yaitu Dinas Kelautan dan Perikanan Provinsi Sumatera Barat selaku leading sector dari program GPEMP berupa sumber data berbentuk dokumen seperti petunjuk teknis atau petunjuk pelaksanaan program GPEMP, Surat Keputusan Gubernur tentang pembentukan tim GPEMP Provinsi Sumatera Barat, dokumen anggaran, laporan pelaksanaan dan lain sebagainya dan BPS Provinsi Sumatera Barat dengan sumber data yang relevan dengan penelitian seperti data kemiskinan, serta Satuan Kerja Perangkat Daerah (SKPD)/instansi terkait lainnya yang ikut serta dalam program GPEMP.

Dalam menganalisa data, ada beberapa data yang menjadi fokus dalam penelitian ini, yaitu a) Untuk mengetahui tahap pelaksanaan GPEMP di Kelurahan Pasie Nan Tigo akan memperbandingkan antara apa yang dihasilkan di lapangan dengan apa yang seharusnya dilakukan sesuai dengan petunjuk pelaksanaan (juklak) program GPEMP dan b) Untuk mengetahui dampak Program GPEMP terhadap orientasi sumber pendapatan keluarga nelayan di Kelurahan Pasie Nan Tigo Kecamatan Koto Tangah Kota Padang dianalisis melalui pendekatan kualitatif dengan mempertanyakan: 1) Jenis sumber pendapatan keluarga nelayan sebelum dan setelah adanya program GPEMP dan 2) Serapan jam kerja tenaga kerja keluarga pada usaha yang dikembangkan dari bantuan program GPEMP.

\section{HASIL DAN PEMBAHASAN}

\section{Tahapan Pelaksanaan Program GPEMP di Kelurahan Pasie Nan Tigo}

Pelaksanaan GPEMP di Kelurahan Pasie Nan Tigo sesuai dengan rencana lokasi pelaksanaan dilaksanakan pada tahun 2012 . Namun, setelah turun ke lapangan dan melakukan wawancara, selain tahun 2012 juga terdapat beberapa kegiatan GPEMP yang dilaksanakan pada tahun 2014. Kegiatan yang dilaksanakan pada tahun 2014 adalah pengembangan budidaya ikan dan bantuan ternak sapi lokal. Hal ini disebabkan karena kegiatan tersebut belum mencapai sasaran di lokasi kelurahan Pasie Nan Tigo pada tahun 2012 dan pada tahun 2014 masih memiliki ketersediaan dana untuk melaksanakannya.

Berdasarkan hasil wawancara dan pengamatan langsung di lapangan, secara teknis tahap-tahap pelaksanaan program GPEMP telah dilaksanakan sesuai dengan petunjuk pelaksanaan. Kecuali dalam tahap penyerahan bantuan GPEMP yaitu bantuan pengembangan budidaya ikan dengan bantuan berupa paket jaring tancap dan peralatan budidaya nila ada terdapat perbedaan spesifikasi barang yang diserahkan dengan yang seharusnya.

Bantuan GPEMP yang diberikan sangat memberikan manfaat kepada nelayan penerima di kelurahan Pasie Nan Tigo. Namun, juga ada beberapa bantuan yang tidak dapat dimanfaatkan oleh keluarga nelayan. Adapun bantuan yang tidak dapat dimanfaatkan oleh keluarga nelayan adalah: 1) lemari asap, tidak sesuai dengan jenis ikan yang akan diolah oleh keluarga nelayan. Pengolahan ikan pukek yang dihasilkan oleh nelayan Pasie Nan Tigo tidak menggunakan lemari asap. Pengolahan ikan kering hanya menggunakan tunggu rebus dan balet penjemur pada saat panas terik; 2) jaring tancap, budidaya ikan nila tidak nerhasil karena kondisi lingkungan dimana budidaya dilakukan di muara suangai yang terkena pasang surut air laut serta paket bantuan yang tidak sesuai dengan spesifikasi;dan 3) bantuan bibit sirsak, penerima tidak mengetahui bagaimanan cara menanam pohon sirsak yang baik serta kemungkinan jenis tanah pasir yang ada di kelurahan Pasie Nan Tigo yang tidak cocok untuk tanaman pohon sirsak.

Dari hasil wawancara dan pengamatan di lapangan, ketidakberhasilan kegiatan GPEMP ini menunjukkan adanya pelaksanaan dalam proses identifikasi yang gagal untuk identifikasi kebutuhan calon penerima GPEMP dan penyerahan bantuan yang tidak terlaksana sesuai dengan pedoman yang seharusnya. Potensi yang mampu untuk dikembangkan di kelurahan Pasie Nan Tigo tidak terpetakan dengan baik. Proses identifikasi belum mampu memetakan potensi yang bisa dikembangkan 
di Kelurahan Pasie Nan Tigo sesuai dengan apa yang dibutuhkan oleh nelayan serta bagaimana kondisi lingkungannya. Serta tidak adanya kontrol atau pengecekan kembali dari dinas terkait yang bertanggung jawab kepada rekanan mengenai spesifikasi bantuan yang akan diserahkan apakah sudah sesuai dengan yang seharusnya.

Tabel 3. Pelaksanaan Program Gerakan Pensejahteraan Ekonomi Masyarakat Pesisir (GPEMP) di Kelurahan Pasie Nan Tigo

\begin{tabular}{|c|c|}
\hline Tahapan Pelaksanaan & $\begin{array}{l}\text { (Sesuai / Tidak } \\
\text { dengan } \\
\text { Petunjuk } \\
\text { Pelaksanaan) }\end{array}$ \\
\hline Penyebaran Informasi & Sesuai dengan \\
\hline Gerakan Pensejahteraan & Petunjuk \\
\hline Ekonomi Masyarakat & Pelaksanaan \\
\hline Pesisir (GPEMP) & \\
\hline $\begin{array}{l}\text { Menentukan Kecamatan } \\
\text { serta }\end{array}$ & Sesuai dengan \\
\hline Nagari/Desa/Kelurahan & Petunjuk \\
\hline yang akan dijadikan & Pelaksanaan \\
\hline Sasaran Program & \\
\hline GPEMP & Sesuai dengan \\
\hline Identifikasi & Petunjuk \\
\hline Penetapan & Pelaksanaan \\
\hline Penerima & Ada yang tidak \\
\hline GPEMP & sesuai dengan \\
\hline Penyerahan & petunjuk \\
\hline Bantuan GPEMP & pelaksanaan \\
\hline
\end{tabular}

Pemanfaatan

Lemari asap

tidak

termanfaatkan

Analisis

pengamatan langsung di lapangan, bagaimana program GPEMP dilaksanakan di Kelurahan Pasie Nan Tigo dapat diuraikan dalam tabel di bawah ini :

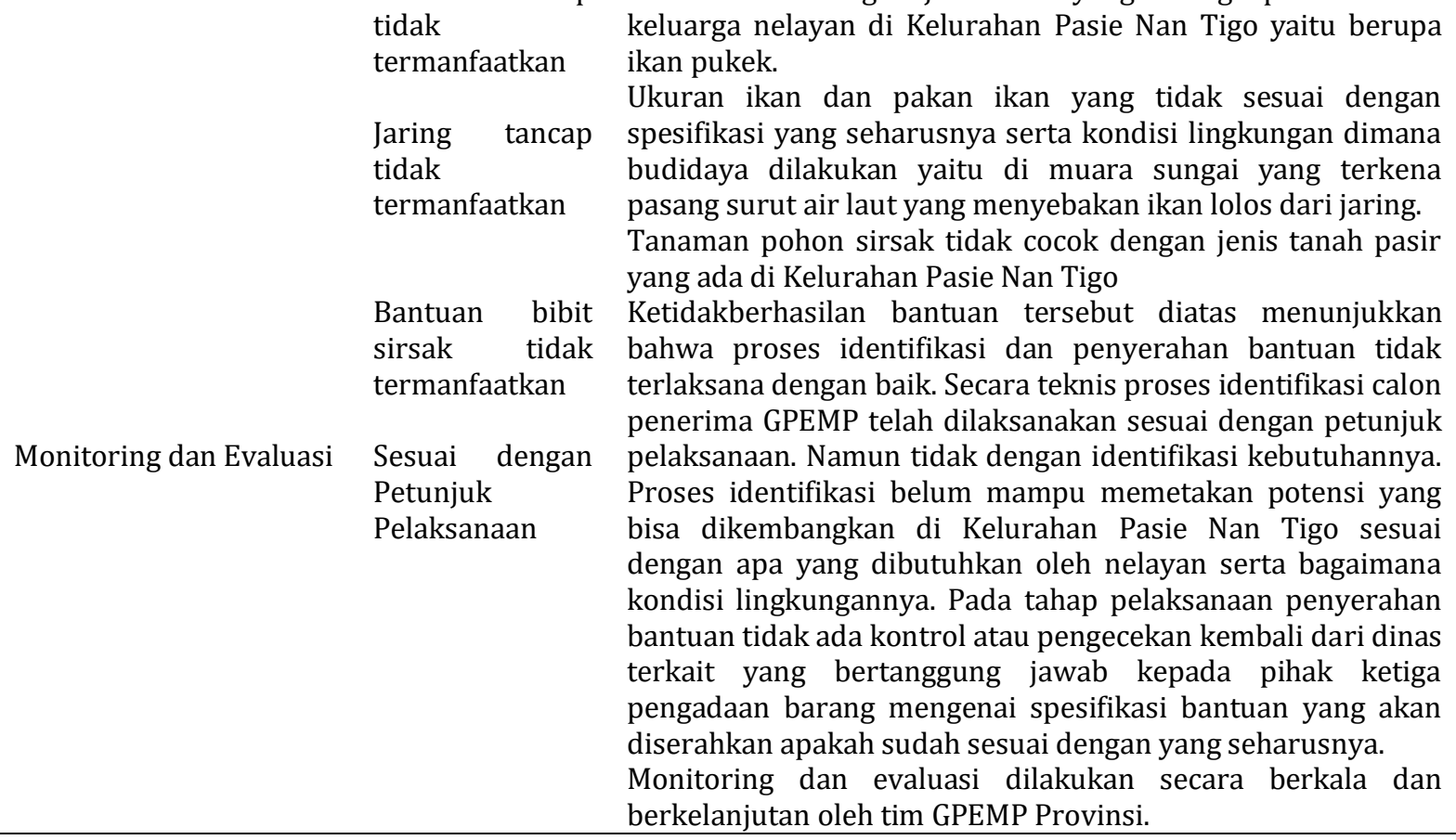




\section{Jenis Sumber Pendapatan Keluarga Nelayan}

Dari hasil wawancara dan pengamatan langsung di lapangan disimpulkan bahwa sebelum program GPEMP jenis sumber pendapatan keluarga nelayan miskin di Kelurahan Pasie Nan Tigo mengandalkankan dari kegiatan penangkapan ikan yang dilakukan secara tradisional dengan perahu tanpa motor dengan pendapatan rata-rata sebesar Rp600,000.00 hingga Rp750,000.00 perbulan, walaupun pendapatan dari penangkapan ikan bervariasi setiap hari atau bulan tergantung cuaca dan hasil tangkap tetapi dapat disimpulkan bahwa sebelum adanya bantuan program GPEMP pendapatan keluarga nelayan hanya ditopang dari penangkapan ikan.

Setelah adanya program GPEMP, penangkapan ikan yang menjadi sumber pendapatan utama keluarga nelayan diperkuatteknologinya dengan pengembangan alat gerak perahu berupa mesin long tail dapat meningkatkan pendapatan nelayan berkisar Rp1,200,000.00 hingga Rp 3,600,000.00 jika melaut setiap hari. Namun tetap pendapatan berbulan bervariasi tergantung keadaan cuaca apakah cukup baik untuk melaut serta juga tergantung dengan jumlah dari hasil tangkapan ikan. Selain itu keluarga nelayan juga memiliki mata pencaharian alternatif lain sebagai sumber pendapatan baru. Hal ini menyebabkan jumlah pendapatan keluarga nelayan menjadi meningkat tergantung pada usaha/ kegiatan lainpendapatan rata-rata sebesar Rp1,200,000.00 per bulan. Nelayan penerima bantuan ternak sapi lebih menjadikan hasil ternak sapi sebagai tabungan yang sewaktu-waktu ada keperluan mendesak/ insedentil dapat dipergunakan seperti membeli kendaraan sepeda motor, menikahkan anak, biaya masuk sekolah dan keperluan lainnya. Pendapatan rata-rata usaha beternak sapi jika dihitung perbulan sebesar Berdasarkan hasil wawancara dan pengamatan langsung di lapangan kepada beberapa informan kunci, keluarga nelayan yang memiliki usaha pengolahan ikan tambahan pendapatan berkisar $\mathrm{Rp} \quad 1,500,000.00$ hingga Rp2,000,000.00 bulan. Keluarga nelayan penerima bantuan budidaya ikan lele mendapat tambahan pendapatan rata-rata sebesar Rp.1,200,000,-/bulan. Nelayan penerima bantuan ternak sapi lebih menjadikan hasil ternak sapi sebagai tabungan yang sewaktu-waktu ada keperluan mendesak/ insedentil dapat dipergunakan seperti membeli kendaraan sepeda motor, menikahkan anak, biaya masuk sekolah dan keperluan lainnya. Pendapatan rata-rata usaha beternak sapi jika dihitung perbulan sebesar Rp.216,000,/bulan ini linier dengan upah mencari rumput atau pakan selama sebulan. Tetapi apabila dihubungkan dengan keperluan peruntukannya sebagai tabungan untuk keperluan mendadak atau keperluan biaya lebih keluarga, pendapatan dari ternak sapi menjadi signifikan dikonversikan dengan harga penjualan satu ekor sapi mampu memenuhi kebutuhan pengeluaran keluarga nelayan.

Keseluruhan bantuan program GPEMP diatas menimbulkan dampak pada jenis sumber pendapatan nelayan dimana sebelum adanya program GPEMP jenis sumber pendapatan keluarga nelayan berasal dari penangkapan ikan dan sesudah adanya program GPEMP keluarga nelayan memiliki mata pencaharian alternatif yang menjadi jenis sumber pendapatan baru keluarga antara lain yaitu diversifikasi pengolahan ikan, budidaya ikan lele dan beternak sapi. Dengan adanya penambahan jenis sumber pendapatan baru tentu juga mempengaruhi peningkatan pendapatan keluarga nelayan penerima bantuan program GPEMP.

\section{Serapan Jam Kerja Tenaga Kerja Keluarga Nelayan}

Berdasarkan hasil wawancara dan pengamatan langsung di lapangan bahwa program GPEMP memberikan dampak pada serapan jam kerja tenaga kerja keluarga nelayan. Kegiatan dari bantuan GPEMP mampu meningkatkan waktu produktif nelayan setelah menangkap ikan di laut yang awalnya 5-6 jam menjadi 7-8 jam dengan melakukan kegiatan beternak sapi dan budidaya ikan. Sehingga diharapkan dapat mengurangi masalah sosio kultural nelayan yang memiliki kebiasaan yang merugikan 
saat tidak melaut seperti duduk di warung atau berjudi.

Selain itu program GPEMP juga dapat meningkatkan peran serta dan partisipasi istri nelayan/ perempuan pesisir dan anak nelayan yang selama ini menjadi menjadi beban tanggungan nelayan tradisional dan tidak produktif dalam menopang ekonomi keluarga nelayan kemudian berperan aktif dalam membantu nelayan dalam proses usaha mata pencaharian altenatif seperti dalam beternak sapi dan budidaya ikan dan atau secara mandiri melaksanakan usaha

Tabel 4. Dampak program Gerakan Pensejahteraan Ekonomi Masyarakat Pesisir (GPEMP) terhadap orientasi pendapatan keluarga nelayan sendiri seperti istri nelayan/ perempuan pesisir yang melaksanakan usaha pengolahan ikan baik perorangan dan berkelompok. Hal ini merupakan bentuk pemberdayaan perempuan dan anak nelayan, yang berhasil secara skala kecil di Kelurahan Pasie Nan Tigo.

Berdasarkan hasil wawancara dan pengamatan langsung di lapangan, dampak program GPEMP terhadap orientasi pendapatan keluarga nelayan dapat diuraikan dalam tabel sebagai berikut:

\begin{tabular}{|c|c|c|}
\hline Aspek & Sebelum Program GPEMP & Sesudah Program GPEMP \\
\hline $\begin{array}{l}\text { Volume } \\
\text { Penangkapan }\end{array}$ & Sedikit & Meningkat \\
\hline $\begin{array}{l}\text { Sumber } \\
\text { Pendapatan }\end{array}$ & $\begin{array}{l}\text { Sebagian besar rumah tangga } \\
\text { nelayan memiliki satu sumber } \\
\text { pendapatan yaitu penangkapan } \\
\text { ikan di laut }\end{array}$ & $\begin{array}{l}\text { Sebagian besar rumah tangga nelayan } \\
\text { penerima program GPEMP memiliki sumber } \\
\text { pendapatan selain penangkapan ikan di laut } \\
\text { seperti diversifikasi pengolahan ikan, } \\
\text { budidaya ikan dan beternak sapi }\end{array}$ \\
\hline $\begin{array}{l}\text { Nilai Tambah } \\
\text { Hasil } \\
\text { Penangkapan } \\
\text { Ikan }\end{array}$ & Sebagian besar di jual segar & Jumlah ikan yang diolah meningkat \\
\hline Jam Kerja & $\begin{array}{l}\text { Kepala keluarga hanya } \\
\text { menangkap ikan } \\
\text { ( } 5-6 \text { jam sehari })\end{array}$ & $\begin{array}{l}\text { Kepala keluarga tetap menangkap ikan } \\
\text { ditambah jam kerjanya dengan budidaya ikan } \\
\text { atau beternak sapi. Konsekunsi ikutannya } \\
\text { persoalan sosio kultural nelayan yang } \\
\text { memiliki kebiasaan yang merugikan saat tidak } \\
\text { melaut berkurang. }\end{array}$ \\
\hline $\begin{array}{l}\text { Keterlibatan } \\
\text { Istri }\end{array}$ & $\begin{array}{l}\text { Sebagian besar istri hanya } \\
\text { mengurus urusan domestik } \\
\text { rumah tangga }\end{array}$ & $\begin{array}{l}\text { Ikut serta dalam kegiatan produksi (mengolah } \\
\text { hasil penangkapan ikan, budidaya ikan dan } \\
\text { beternak sapi). }\end{array}$ \\
\hline $\begin{array}{l}\text { Keterlibatan } \\
\text { Anak }\end{array}$ & $\begin{array}{l}\text { Anak laki - laki usia produktif } \\
\text { tidak mau ikut melaut karena } \\
\text { kegiatan menangkap ikan } \\
\text { masih dilakukan secara manual } \\
\text { dengan mendayung perahu. } \\
\text { Anak nelayan (laki - laki / } \\
\text { perempuan) tidak ikut serta } \\
\text { dalam kegiatan produksi } \\
\text { keluarga }\end{array}$ & $\begin{array}{l}\text { Anak laki - laki usia produktif ikut melaut } \\
\text { karena sudah menggunakan perahu dengan } \\
\text { motor. Konsekunsi ikutannya persolaan } \\
\text { kenakalan remaja berkurang. } \\
\text { Anak nelayan (laki - laki / perempuan) ikut } \\
\text { serta dalam kegiatan produksi keluarga. }\end{array}$ \\
\hline
\end{tabular}


Program GPEMP memberikan dampak yang positif bagi keluarga nelayan miskin di Kelurahan Pasie Nan Tigo. Program GPEMP memperkuat teknologi usaha yang nelayan lakukan selama ini yaitu menangkap ikan dengan bantuan berupa alat gerak perahu berupa mesin long tail dan mempertahankan mutu hasil penangkapan ikan dengan fish box, mampu memberikan mata pencaharian alternatif lain bagi keluarga nelayan baik itu masih berbasiskan sumber daya kelautan dan perikanan seperti budidaya ikan lele, mendorong tumbuh kembangnya usaha diversifikasi olahan produk hasil perikanan dengan skala indsutri rumah tangga serta memfasilitasi dan mengembangkan usaha lainnya di luar bidang kelautan dan perikanan yaitu dengan beternak sapi. Dengan demikian keluarga nelayan mampu meningkatkan pendapatan keluarga nelayan yang mempengaruhi berkurangnya tingkat kemiskinan di keluarga nelayan Kelurahan Pasie Nan Tigo.

Menurut Saldanha (1998), persoalan kemiskinan mengandung enam masalah pokok yaitu: 1) masalah kerentanan; 2) tertutupnya akses kepada berbagai peluang kerja; 3) masalah ketidakpercayaan; 4) kemiskinan berarti menghabiskan semua atau sebagian besar penghasilannya untuk konsumsi; 5) tingginya rasio ketergantungan; dan 6) budaya kemiskinan yang diwariskan dari satu generasi ke generasi lainnya. Permasalahanpermasalahan pokok kemiskinan tersebut didapat bahwa program GPEMP mampu mengatasinya. Terkait masalah kerentanan, nelayan penangkap ikan sangat bergantung dengan keadaan cuaca. Jika cuaca buruk nelayan terpaksa tidak melaut, selain itu resiko melaut yang tinggi mengakibatkan pekerjaan ini hanya dilakukan oleh lelaki. Dengan adanya mata pencaharian lain selain penangkapan ikan di laut mengurangi resiko ketergantungan yang tinggi terhadap okupasi laut. Program GPEMP memberikan kepercayaan kepada keluarga nelayan miskin bahwa keluarga nelayan mempunyai kemauan dan semangat untuk pengembangan ekonomi keluarganya dengan memfasilitasi dan mengembangkan usaha-usaha baik itu masih berbasiskan sumber daya keluatan dan perikanan seperti budidaya ikan lele dan diversifikasi pengolahan ikan ataupun usaha lainnya di luar bidang kelautan dan perikanan seperti beternak sapi sehingga membuka akses berbagai peluang kerja. Dengan adanya berbagai peluang kerja, keterlibatan istri dan anak usia produktif semakin besar dalam kegiatan produksi keluarga nelayan. Selain itu dengan adanya kegiatan usaha seperti beternak sapi, keluarga nelayan juga mempunyai tabungan untuk kebutuhan yang bersifat insedentil atau mendadak.

\section{Menurut Waluyo (2014), secara} keruangan dan ekologis wilayah pesisir memiliki keterkaitan antara lahan atas (daratan) dan laut lepas. Hal ini disebabkan karena wilayah pesisir merupakan daerah pertemuan antara daratan dan laut. Dengan keterkaitan kawasan tersebut, maka pengelolaan kawasan pesisir dan laut tidak terlepas dari pengelolaan lingkungan yang dilakukan di kedua kawasan tersebut. Berbagai kegiatan pembangunan yang dapat dilakukan di lahan atas, seperti pertanian, perkebunan, kehutanan, industri, pemukiman dan sebagainya, demikian juga dengan kegiatan yang dilakukan di laut lepas, seperti kegiatan pengeboran minyak lepas pantai dan perhubungan laut

Program GPEMP merupakan program pembangunan wilayah pesisir sebagaimana menurut Lasabuda (2013) bahwa pembangunan wilayah pesisir meliputi pengelolaan sumberdaya kelautan dan perikanan membutuhkan kebijakan yang komprehensif, terintegrasi dan tepat sasaran, mengingat kawasan ini memiliki permasalahan, potensi dan karakteristik yang khas. Program GPEMP secara terpadu memberdayakan rumah tangga masyarakat pesisir/nelayan melalui peningkatan jenis usaha dan jam kerja efektif untuk mewujudkan kesejahteraan masyarakat pesisir/nelayan dengan didukung oleh instansi dari berbagai sektor yaitu Dinas Kelautan dan Perikanan, Pertanian dan Tanaman Pangan, Peternakan, Kehutanan, Sekretariat Bakorluh dan instansi lainnya di Provinsi Sumatera Barat.

Menurut Kurniadi et al. (2013), pemberdayaan masyarakat bukanlah sekedar untuk memenuhi kebutuhan dasar atau menyediakan mekanisme pencegahan proses pemikiran lebih lanjut. Konsep ini dikembangkan dari upaya banyak ahli dan praktisi untuk mencari upaya seperti "alternative development" yang menghendaki "Inclusive democracy, approriate economic 
growth, gender equality and inter-generational equity'. Ini berarti perempuan tidak lagi hanya berperan sebagai ibu rumah tangga yang menjalankan fungsi reproduksi, mengurus anak dan suarni atau pekerjaan domestik lainnya, tetapi sudah aktif berperan di berbagai bidang kehidupan, baik sosial, ekonomi maupun politik.

Program GPEMP dapat meningkatkan peran serta dan partisipasi istri nelayan/ perempuan pesisir dan anak nelayan yang selama ini menjadi tanggungan nelayan dan tidak produktif menompang ekonomi nelayan kemudian berperan aktif dalam membantu nelayan dalam proses usaha mata pencaharian alternatif dan atau secara mandiri melaksanakan usaha sendiri seperti istri nelayan/perempuan pesisir yang melaksanakan usaha pengolahan ikan baik perorangan dan berkelompok. Disamping itu keterlibatan anak nelayan dalam proses penangkapan ikan di laut, membantu nelayan dalam usaha budidaya ikan atau ternak sapi, mampu memberikan dampak positif dalam meningkatkan pendapatan keluarga nelayan. Hal ini menunjukan pada program GPEMP adanya pemberdayaan perempuan pesisir dan anak nelayan sebagaimana menurut Sulistiyani (2007), bahwa pemberdayaan melalui proses penyerahan kekuasaan dari pemerintah kepada yang tidak berdaya (masyarakat miskin), dimaksudkan supaya masyarakat dapat memiliki kekuatan untuk membangun, serta dapat meningkatkan daya sehingga memiliki kemampuan untuk membangun.

Berdasarkan Laporan Akhir Kajian Dampak Program Gerakan Pensejahteraan Masyarakat Pesisir (GPEMP) Provinsi Sumatera Barat (TK2D GPEMP, 2015), hasil evaluasi lokasi program GPEMP di Kota Padang memiliki tingkat keberhasilan berkisar $45 \%$. Jenis bantuan yang berhasil tersebut adalah kelompok bantuan paket perikanan tangkap yaitu mesin kapal/long tail dan paket pengolahan hasil perikana yaitu fish box. Tingginya tingkat keberhasilan paket ini dibandingkan paket yang lain disebabkan oleh karena jenis paket ini langsung digunakan oleh nelayan untuk kegiatan penangkapan ikan. Dari hasil yang didapatkan dari wawancara dan pengamatan langsung di lapangan, jika tingkat keberhasilan dilihat dari tingkat pemanfaatan bantuan, program GPEMP memang tidak berhasil 100\%. Namun, program GPEMP memberikan dampak yang positif bagi nelayan. Paket bantuan penangkapan ikan, budidaya ikan lele dan ternak sapi dapat dimanfaatkan secara maksimal. Tetapi tidak dengan paket pengolahan hasil perikanan berupa lemari asap, budidaya ikan nila dengan jaring tancap dan bantuan bibit pohon sirsak. Kegagalan paket bantuan GPEMP ini disebabkan karena paket bantuan yang diberikan tidak sesuai dengan kebutuhan nelayan serta kondisi lingkungan di Kelurahan Pasie Nan Tigo. Selain itu pake bantuan yang diberikan tidak sesuai dengan spesifikasi yang seharusnya.

\section{SIMPULAN}

Pelaksanaan program Gerakan Pensejahteraan Ekonomi Masyarakat Pesisir (GPEMP) di Kelurahan Pasie Nan Tigo dilaksanaan dalam beberapa tahap yaitu: 1) penyebaran informasi GPEMP; 2) menentukan lokasi GPEMP; 3) identifikasi dan penetapan calon penerima bantuan; 4) penyerahan bantuan; dan 5) monitoring dan evaluasi. Tahapan sudah dilaksanakan sesuai dengan petunjuk pelaksanaan kecuali dalam tahap penyerahan bantuan pengembangan budidaya ikan. Bantuan paket jaring tancap dan peralatan budidaya nila terdapat perbedaan spesifikasi barang yang diserahkan dengan yang seharusnya.

Program GPEMP berdampak pada perubahan orientasi sumber pendapatan keluarga nelayan, yaitu: 1) jenis sumber pendapatan keluarga nelayan tidak hanya dari penangkapan ikan tetapi juga dari mata pencaharian alternatif sebagai sumber pendapatan baru yaitu budidaya ikan, diversifikasi pengolahan ikan dan beternak sapi; dan 2) serapan jam kerja tenaga kerja nelayan bertambah serta adanya keterlibatan istri dan anak nelayan dalam melakukan usaha.

\section{DAFTAR PUSTAKA}

Creswell, J.W.(1998).Qualitative Inquiry and Research Design: Choosing among Five Tradition. London: Sage Publications.

Dahuri, R. et al.(1996). Pengelolaan Sumberdaya Pesisir dan Lautan Secara Terpadu. Jakarta: PT. Pramadya Paramita

Hamdani, H. (2013). Faktor Penyebab Kemiskinan nelayan Tradisional. Artikel Ilmiah Hasil 
Thahira Kemala dewi, Asdi Agustar \& Mahdi, Pelaksanaan Program Gerakan Pensejahteraan Ekonomi

Penelitian Mahasiswa 2013, Universitas Jember.

Kurniadi, H., Pahlevi, M.R., \& Purnomo, T. (2017), Pengembangan Peran Perempuan Pesisir Di Muncar: Analisis Dan Pemetaan Kualitas Sumber Daya Pada Perempuan Muda. Prosiding Seminar Nasional dan Call For Paper Ekonomi dan Bisnis (SNAPER-EBIS 2017), 597-607.

Kusnadi.(2002).Konflik Sosial Nelayan, Kemiskinan dan Perebutan SumberdayaPerikanan. Yogyakarta: LKIS.

Lasabuda, R. (2013). Pembangunan Wilayah Pesisir Dan Lautan Dalam Perspektif Negara Kepulauan Republik Indonesia. Jurnal Ilmiah Platax, 1 (2).

Novita, A. W. (2016). Strategi Nelayan Dalam Memenuhi Kebutuhan Rumah Tangga (Studi Kasus Di Desa Tateli Dua Kecamatan Mandolang Kabupaten Minahasa Provinsi
Sulawesi Utara). Jurnal Ilmiah Agrobisnis Perikanan, 4 (1), 229-238.

Saldanha, J. (1998). Pertumbuhan Ekonomi, Survei Ekonommi Politik di Indonesia. Analisis CSIS Studi Pembangunan Politik, Pertumbuhan dan Kerja Intelektual, 2, 126-151.

Sulistyani., A.T. (2007). Konseptual Model Pemberdayaan LSM sebagai Fasilitator Pembangunan. JKAP(Jurnal Kebijakan dan Administrasi Publik), 11 (2), 139-157.

[TK2D GPEMP] Tim Kerja Kajian Dampak GPEMP Sumatera Barat. 2015. Laporan Kajian Dampak Program Gerakan Pensejahteraan Masyarakat Pesisir (GPEMP) Provinsi Sumatera Barat. Padang: DKP Prov. Sumbar.

Waluyo, A. (2014), Permodelan Pengelolaan Wilayah Pesisir Dan Pulau-Pulau Kecil Secara Terpadu Yang Berbasis Masyarakat (Studi Kasus Pulau Raas Kabupaten Sumenep Madura). Jurnal Kelautan, 7 (2). 